\title{
ANALISA PERFORMA MESIN DAN KADAR EMISI GAS BUANG KENDARAAN BERMOTOR DENGAN MEMANFAATKAN BIOETANOL DARI BAHAN BAKU SINGKONG SEBAGAI BAHAN BAKAR ALTERNATIF CAMPURAN PERTALITE
}

\author{
Imam Prasetyo, Sarjito, Marwan Effendy \\ ${ }^{1}$ Teknik Mesin Universitas Muhammadiyah Surakarta \\ Jl. A. Yani Tromol Pos 1 Pabelan, Kartosuro
}

Email :sarjito@ums.ac.id

\begin{abstract}
ABSTRAK
Bahan bakar fosil saat ini keberadaannya semakin langka, dan diperlukan langkahlangkah pencarian bahan bakar alternatif yang layak untuk menggantikan bahan bakar minyak, terutama bensin, yang kebutuhannya sangat banyak untuk kendaraan bermotor. Salah satu bahan bakar alternatif pengganti bensin adalah bioetanol (BE). Penelitian ini membahas tentang bagaimana pembuatan bioetanol dari bahan baku singkong, kemudian diuji performa mesin untuk mengetahui daya, torsi yang paling optimal dari variasi jenis busi standar dan busi platinum dengan memakai bahan bakar pertalite murni, lalu di uji kembali performa mesin untuk mengetahui daya, torsi, konsumsi bahan bakar dan kadar emisi gas buang yang dihasilkan dari penggunaan variasi campuran bahan bakar bioetanol dengan variasi BE 10\%, BE 20\% dan BE 30\% dengan memakai jenis busi yang paling optimal. Dari hasil pengujian menunjukkan bahwa dengan menggunakan bioetanol, daya yang dihasilkan dari mesin semakin meningkat seiring meningkatnya kadar bioetanol dalam campuran bahan bakar, namun pada torsi yang dihasilkan oleh mesin cenderung menurun pada penggunaan bahan bakar bioetanol. Lalu pada konsumsi bahan bakar semakin hemat dengan menggunakan bahan bakar BE 30\%, hal ini didasarkan jarak tempuh dengan memakai bahan bakar BE 30\% lebih jauh dari pada memakai bahan bakar pertalite 100\%. Sedangkan hasil emisi gas buang pada kendaraan menunjukkan bahwa dengan menggunakan bahan bakar bioethanol emisi gas buang yang dihasilkan semakin menurun seiring meningkatnya kadar bioetanol dalam campuran bahan bakar dari pada emisi gas buang yang dihasilkan dengan menggunakan bahan bakar pertalite 100\%. Dan dibuktikan melalui metode analisa data statistik dengan Varian ANOVA satu jalan (Uji F) untuk daya, torsi dan kadar emisi HC, didapat nilai F hitung < F tabel, maka Ho diterima, sehingga hasil dari setiap variasi bahan bakar tidak ada perbedaan yang signifikan. Namun untuk kadar CO, didapat nilai F hitung $>$ F tabel, maka Ho ditolak, sehingga hasil dari setiap variasi bahan bakar ada perbedaan yang signifikan.
\end{abstract}

Kata kunci: Bioetanol, Singkong, Performa Mesin, Emisi Gas Buang

\begin{abstract}
Fossil fuels are now becoming increasingly scarce, and steps are needed to find suitable alternative fuels to replace oil fuels, especially gasoline, which are very much needed for motorized vehicles. One alternative fuel for gasoline is bioethanol (BE). This study
\end{abstract}


discusses how to make bioethanol from cassava raw material, then tests the engine performance to determine the power, the most optimal torque from a variety of standard spark plugs and platinum plugs using pure pertalite fuel. After that, tests of the engine's performance is continuing to determine power, torque, fuel consumption and the level of exhaust emissions resulting from the use of variations in the mixture of bioethanol fuel with variations of BE 10\%, BE 20\% and BE $30 \%$ by using the most optimal type of spark plug. The test results show that by using bioethanol, the power generated from the engine increases with increasing levels of bioethanol in the fuel mixture, but the torque produced by the engine tends to decrease in the use of bioethanol fuel. The most efficient fuel consumption is by using $30 \%$ BE fuel, this is based on the driving distance by using BE fuel $30 \%$ is further than using 100\% pertalite fuel. Moreover, the results of exhaust emissions on vehicles show that by using bioethanol fuel the resulting exhaust emissions decrease with increasing levels of bioethanol in the fuel mixture compared to the exhaust emissions produced by using 100\% pertalite fuel. This is also proved by the method of statistical data analysis with one-way ANOVA Variant (F Test) for power, torque and HC emission levels. It is obtained that $F$ value $<F$ table, then Ho is accepted showing that there is no significant difference between the results of each variation of fuel. However, for $C O$ levels, it is obtained that $F$ count $>F$ table, then Ho is rejected, indicating that there are significant differencesof the results of each variation of fuel.

\section{Keywords: Bioethanol, Cassava, Engine Performance, Exhaust Emissions}

\section{PENDAHULUAN}

Kelangkaan bahan bakar minyak yang terjadi belakangan ini telah memberikan dampak yang sangat luas di berbagai sektor kehidupan. Sektor yang paling cepat terkena dampaknya adalah sektor transportasi. Fluktuasi suplai dan harga minyak bumi seharusnya membuat kita sadar bahwa jumlah cadangan minyak yang ada di bumi semakin menipis. Karena minyak bumi adalah bahan bakar yang tidak bisa diperbarui maka kita harus mulai memikirkan bahan penggantinya. Sebenarnya di Indonesia terdapat berbagai sumber energi terbarukan yang melimpah, seperti biodiesel dari tanaman jarak pagar, kelapa sawit maupun kedelai. Atau methanol dan ethanol dari biomassa, tebu, jagung, dll yang bisa dipergunakan sebagai pengganti bensin.

Selain itu pembakaran bahan bakar fosil ini telah memberikan dampak negatif terhadap lingkungan. Kualitas udara yang semakin menurun akibat asap pembakaran minyak bumi, adalah salah satu efek yang dapat kita lihat dengan jelas. Kemudian efek gas rumah kaca yang ditimbulkan oleh gas $\mathrm{CO}_{2}$ hasil pembakaran minyak bumi. Seperti kita ketahui pembakaran bahan bakar fosil yang tidak sempurna akan menghasilkan gas $\mathrm{CO}_{2}$, yang lama kelamaan akan menumpuk di atmosfer. Radiasi sinar matahari yang dipancarkan kebumi seharusnya dipantulkan kembali ke angkasa, namun penumpukan $\mathrm{CO}_{2}$ ini akan menghalangi pantulan tersebut. Akibatnya radiasi akan kembali diserap oleh bumi yang akhirnya meningkatkan temperatur udara di bumi [1].

Salah satu sumber penyumbang karbondioksida adalah pembakaran bahan bakar fosil. Penggunaan bahan bakar fosil mulai meningkat pesat sejak revolusi industri pada abad ke-18. Pada saat itu, batu bara menjadi sumber energi dominan untuk kemudian digantikan oleh minyak bumi pada pertengahan abad ke-19. Sumber utama penghasil emisi karbondioksida secara global ada 2 macam. Pertama, pembangkit listrik bertenaga batu bara. Kedua, pembakaran kendaraan bermotor. Emisi gas rumah kaca harus dikurangi, jadi harus dibangun sistem industri 
dan transportasi yang tidak bergantung pada bahan bakar fosil yaitu minyak bumi dan batu bara. Maka untuk mengatasi hal ini diperlukan sumber energi alternatif yang dapat mengurangi penggunaan bahan bakar fosil sekaligus dapat mengurangi emisi karbondioksida. Salah satu sumber energi yang dapat mengurangi pengunaan bahan bakar fosil adalah bahan bakar nabati yaitu bioetanol.

Bioetanol adalah alkohol yang diproduksi dari tumbuh-tumbuhan dengan menggunakan mikroorganisme melalui proses fermentasi. Pengenalan energi alternatif ini juga merupakan upaya untuk mengurangi penggunaan bahan bakar minyak di Indonesia. Bioetanol merupakan bentuk sumber energi alternatif yang menarik untuk dikembangkan karena kelimpahannya di Indonesia dan sifatnya yang dapat diperbarui. Ada 3 kelompok bahan penghasil bioetanol yaitu nira bergula, pati, dan bahan serat alias lignoselulosa. Semua bahan baku bioetanol itu mudah didapatkan dan dikembangkan di Indonesia yang memiliki lahan luas dan subur [2].

Sehingga bioetanol mungkin menjadi calon bahan bakar alternatif dan banyak studi yang dilakukan untuk mengembangkan bahan bakar ini. Bioetanol memiliki sejumlah keunggulan dibandingkan dengan bahan bakar fosil yang dapat langsung dicampur dalam tangki bahan bakar, disuntikkan ke ruang bakar dan dibakar untuk mengurangi emisi gas buang. Bahan ini berasal dari sumber daya terbarukan yang tidak terbatas dalam bentuk tanaman yang dapat tumbuh dengan baik atau biomassa yang mengandung gula, pati atau selulosa. Dengan mencampurkan bioetanol dengan fosil bahan bakar berbasis dalam mesin bensin dapat membantu memperpanjang umur pasokan bahan bakar, menjamin keamanan yang lebih dalam pasokan bahan bakar besar, meningkatkan efisiensi pembakaran dan mengurangi hidrokarbon (HC) dan emisi karbon monoksida (CO). Selain itu, lebih tinggi panas campuran bensin bioetanol membuat campuran yang lebih baik, yang mengarah ke pembakaran yang lebih sempurna. Sehingga mengurangi masalah lingkungan, meningkatkan ekonomi pertanian dan menghindari ketergantungan pada negara-negara bahan bakar penghasil fosil [3].

\section{TINJAUAN PUSTAKA}

Penelitian tentang pemanfaatan bioetanol sebagai campuran bahan bakar pernah dilakukan oleh Mohsen Ghazikhani et al. (2013), dalam penelitiannya melakukan studi eksperimen tentang pengaruh suhu gas buang dan kadar emisi gas buang dari kinerja mesin bensin 2 tak menggunakan bahan bakar bensin campuran etanol. Hasilnya menunjukkan bahwa efesiensi pembakaran meningkat dengan meningkatnya prosentase etanol dalam bahan bakar bensin, karena sifat etanol yang mudah penguap sehingga pembilasan diruang bakar semakin baik dan hasil yang paling menonjol dari menggunakan etanol adalah penurunan polusi yang signifikan yang dipancarkan dari mesin yaitu kadar CO dengan pengurangan 35\% memiliki porsentase penurunan terbesar diantara polutan lainnya. Serta sebagian besar emisi meningkat dengan meningkatkan suhu gas buang, tapi hidrokarbon $(\mathrm{HCs})$ pada rata-rata mengalami penurunan sebesar 30\% pada peningkatan suhu gas buang [4].

Xiaochen Wang et al. (2015), dalam penelitiannya melakukan perbandingan karakteristik pembakaran dan emisi gas buang dengan menggunakan bahan bakar E10W, E10 dan bensin murni (EO) dengan beban mesin yang berbeda yaitu $20 \mathrm{Nm}, 50 \mathrm{Nm}$ dan $100 \mathrm{Nm}$, serta dalam percobaan ini dilakukan dengan kecepatan mesin tetap yaitu $2000 \mathrm{rpm}$. Menurut hasil eksperimennya dibandingkan dengan E0, E10W menunjukkan lebih tinggi puncak tekanan dalam silinder pada beban tinggi, serta kenaikan tingkat pelepasan panas puncak diamati untuk bahan bakar E10W di semua kondisi operasi. Penggunaan E10W meningkatkan kadar NOx pada kisaran beban tinggi. Namun, pada beban kondisi rendah, E10W dapat mengurangi kadar $\mathrm{HC}, \mathrm{CO}$ dan $\mathrm{CO}_{2}$ secara signifikan. Dibandingkan dengan E10, E10W menunjukkan puncak tekanan yang lebih tinggi di dalam silinder. Selain itu, penurunan NOx emisi diamati untuk 
E10W dari $5 \mathrm{Nm}$ menjadi $100 \mathrm{Nm}$, sedangkan $\mathrm{HC}, \mathrm{CO}$ dan $\mathrm{CO}_{2}$ emisi sedikit lebih tinggi pada kondisi beban rendah dan menengah [5].

Paolo Iodice et al. (2013), melakukan penelitian yang cukup simple yaitu pengujian emisi pada sepeda motor dalam keadaan mesin belum mencapai suhu kerja dengan menggunakan bahan bakar bensin di campur dengan etanol. Pada penelitian ini kadar etanol yang digunakan sebesar 10\%, 20\%, 30\% serta kadar emisi yang di ukur hanya CO dan HC. Hasil penelitiannya menunjukkan bahwa kadar emisi CO dan $\mathrm{HC}$ pada mesin dingin menurun dengan menggunakan bahan bakar etanol-bensin dibandingkan dengan penggunaan bensin tanpa timbal, serta faktor kadar emisi pada mesin dingin yang dikuantisasi sebagai fungsi dari prosentase etanol dalam bahan bakar [6].

Bambang Sudarmanta et al. (2016), dalam penelitiannya melakukan studi eksperimen tentang pengaruh rasio kompresi dan waktu pengapian untuk mengetahui kinerja mesin dengan menggunakan bahan bakar E50. Dari hasil penelitian didapat bahwa kenaikan rasio kompresi meningkatkan kinerja mesin dengan menggunakan bahan bakar E50, untuk waktu pengapian secara bertahap meningkat mulai dari $18^{\circ}$ BTDC pada putaran mesin $2000 \mathrm{rpm}$ sampai $26^{\circ}$ BTDC pada putaran mesin $5000 \mathrm{rpm}$ dengan menggunakan bahan bakar E50. Kemudian dengan menambahkan rasio kompresi pada bahan bakar E50 dapat mengurangi konsumsi bahan bakar spesifik 13,42\% dan meningkatkan thermal efisiensi 14,67\% [7].

Yanuandri Putrasari et al. (2013), yang dilakukan dalam penelitiannya yaitu solar dicampur dengan etanol dengan kadar E2.5\%, E5\%, E7.5\%, E10\% dan percobaan ini dilakukan dalam berbagai beban mesin yang berbeda dari 0,10, 20, 30, 40, 50, $60 \mathrm{Nm}$ untuk mengetahui perubahan parameter pada mesin diesel yaitu konsumsi bahan bakar, efesiensi thermal, suhu gas buang dan suhu minyak pelumas, sedangkan untuk karateristik emisi gas buang parameter yang di ukur kadar $\mathrm{CO}$ dan HC. Hasil penelitian ini didapat bahwa tenaga mesin menunjukkan rata-rata peningkatan tekanan efektif dengan meningkatnya prosentase etanol, untuk konsumsi bahan bakar spesifik menurun dengan meningkatnya prosentase etanol, lalu penurunan suhu gas buang dan peningkatan suhu minyak pelumas yang sesuai dengan penambahan prosentase etanol dalam campuran. Serta hasil karateristik emisi gas buang CO, HC menurun karena peningkatan prosentase etanol dalam campuran [8].

\section{KAJIAN TEORI}

Bioetanol adalah etanol yang dihasilkan dari fermentasi glukosa yang dilanjutkan dengan proses destilasi. Etanol merupakan kependekan dari etil alkohol $(\mathrm{C} 2 \mathrm{H} 5 \mathrm{OH})$; sering pula disebut grain alcohol atau alkohol. Wujud dari etanol berupa cairan yang tidak berwarna, mudah menguap dan mempunyai bau yang khas. Berat jenisnya adalah sebesar $0,7939 \mathrm{~g} / \mathrm{mL}$, dan titik didihnya 78,320 C pada tekanan $766 \mathrm{mmHg}$. Sifat lainnya adalah larut dalam air dan eter, serta mempunyai panas pembakaran $7093.72 \mathrm{kkal}$. Etanol digunakan dalam beragam industri seperti sebagai bahan baku industri turunan alkohol, campuran untuk minuman keras seperti sake atau gin, bahan baku farmasi dan kosmetik, dan campuran bahan bakar kendaraan, peningkat oktan, dan bensin alkohol (gasohol) [9].

Pemakaian etanol sebagai sumber energi dalam industri dan kendaraan akan sangat mengurangi pembuangan gas $\mathrm{CO}_{2}$ yang mengakibatkan pemanasan global. Cepat atau lambat sumber minyak (fosil fuel) akan habis karena depositnya terbatas. Minyak bumi merupakan sumber energi yang tidak dapat diperbaharui. Keterbatasan itu mendorong negara industri melirik etanol (biofuel) sebagai sumber energi altenatif. Selain terus-menerus dapat diproduksi oleh mikroorganisme, etanol juga ramah lingkungan.

Beberapa keunggulan dari penggunaan etanol sebagai bahan bakar yaitu:

1. Diproduksi dari tanaman yang bersifat renewable. 
2. Mengandung kadar oksigen sekitar 35\% sehingga dapat terbakar lebih sempurna.

3. Penggunaan gasohol dapat menurunkan emisi gas rumah kaca.

4. Pembakaran tidak menghasilkan partikel timbal dan benzena yang bersifat karsinogenik (penyebab kanker).

5. Mengurangi emisi fine-particulates yang membahayakan kesehatan manusia.

6. Mudah larut dalam air dan tidak mencemari air permukaan dan air tanah

Proses destilasi dapat menghasilkan etanol dengan kadar 95\%, untuk digunakan sebagai bahan bakar perlu lebih dimurnikan lagi hingga mencapai 99,5\% yang sering disebut Fuel Grade Ethanol (FGE). Mengingat pemanfaatan etanol yang beraneka ragam, maka kadar etanol yang dimanfaatkan harus berbeda sesuai dengan penggunaannya. Etanol yang mempunyai kadar 90-96,5\% dapat digunakan pada industri, sedangkan etanol yang mempunyai kadar 96-99,5\% dapat digunakan sebagai campuran untuk miras dan bahan dasar industri farmasi. Etanol yang dimanfaatkan sebagai campuran bahan bakar untuk kendaraan yang harus betul-betul kering dan anhydrous supaya tidak korosif, sehingga etanol harus mempunyai kadar sebesar 99,5$100 \%$. Perbedaan besarnya kadar akan berpengaruh terhadap proses pengolahan karbohidrat menjadi glukosa larut air [10].

\section{METODOLOGI PENELITIAN}

\section{Alat dan Bahan}

Peralatan yang digunakan dalam pengujian adalah sebagai berikut :

1. Motor bensin 4 langkah $110 \mathrm{cc}$

2. Dynotest/Dinamometer

3. Emission Gas Analyzer

4. Tachometer

5. Gelas Ukur

Sedangkan bahan yang digunakan dalam pengujian ini adalah sebagai berikut :

1. Pertalite RON 90

2. Bioetanol FGE $99,5 \%$

3. Busi Standar

4. Busi Platinum

\section{Tahapan Pembuatan Bioetanol}

Pembuatan bioetanol melalui tahapan sebagai berikut (a) persiapan bahan baku, singkong dihancurkan dengan menggunakan mesin parut kelapa, kemudian ditambahkan air sebanyak 1,5 $\mathrm{x}$ berat bahn baku untuk direbus (b) proses liquifikasi, dimana struktur tepung/pati singkong dipecah secara kimia menjadi gula komplek dengan penambahan Enzym Alfa Amylase (c) tahapan selanjutnya proses sakarifikasi, dimana gula komplek dipecah lagi menjadi gula sederhana dengan prosentase rendah (10-12\%) dengan penambahan Enzym Gluco Amylase (d) Fermentasi, pada tahap ini dimana tepung telah berubah menjadi gula sederhana untuk difermentasi agar menghasilkan cairan etanol/alcohol dengan kadar (2-5\%) dengan penambahan ragi, proses ini berlangsung kurang lebih 5-7 hari diwadah tertutup (e) Destilasi atau penyulingan dilakukan untuk memisahkan alkohol dari cairan hasil fermentasi. Dalam proses distilasi, pada suhu $78^{\circ} \mathrm{C}$ (setara dengan titik didih alkohol) bioetanol akan menguap lebih dulu ketimbang air yang bertitik didih $100^{\circ} \mathrm{C}$. Lalu uap bioetanol yang ada dalam alat distillator akan dialirkan kebagian kondensor sehingga terkondensasi menjadi cairan etanol dengan kadar $70-95 \%$ (f) Dehidrasi pemurnian etanol yang berkadar $70-95 \%$ dengan beberapa cara antara lain secara 
kimia dengan menggunakan batu gamping, secara fisika ditempuh melalui proses penyerapan menggunakan Zeolite Sintesis. Hasil dehidrasi berupa etanol dengan kadar 99,6-99,8 \%, dikenal dengan istilah Fuel Grade Ethanol (FGE) atau disebut etanol kering. Barulah bioetanol ini layak digunakan sebagai campuran bahan bakar motor.

\section{Pengujian Kinerja Mesin}

Pengujian kinerja mesin ini bertujuan untuk mengetahui performa mesin yang paling optimal dari variasi jenis busi standar dan busi platinum dengan memakai bahan bakar pertalite murni, lalu di uji kembali performa mesin untuk memperoleh data yang selanjutnya digunakan untuk mengetahui daya, torsi, konsumsi bahan bakar dan kadar emisi gas buang yang dihasilkan dari penggunaan variasi campuran bahan bakar bioetanol dengan variasi BE $10 \%$, BE 20\% dan BE 30\% dengan memakai jenis busi yang paling optimal.

\section{Teknik Analisa Data}

Penelitian ini menggunakan dua metode analisis yang pertama dengan menggunakan metode analisa data deskriptif. Dimana data yang diperoleh dari hasil pengujian eksperimen dimasukkan ke dalam tabel, dan ditampilkan dalam bentuk grafik kemudian dibandingkan dan dianalisis performa mesin dan kadar emisi gas buang kendaraan dari hasil variasi bahan bakar bioetanol yang berbeda dengan kadar 10\%, 20\% dan 30\%. Metode analisa yang kedua dengan uji analisa data statistik dengan menggunakan uji t (regresi ganda), uji One Sample T Test dan uji varian ANOVA satu jalan (uji F) dengan bantuan program SPSS. Dimana data yang diperoleh dari hasil pengujian eksperimen dimasukkan ke program SPSS untuk diolah dan dianalisa data secara komputer untuk mengetahui dari pada hasilnya secara analisa data apakah ada pengaruh atau perbedaan yang signifikan dari hasil menggunakan variasi bahan bakar bioetanol terhadap performa mesin dan kadar emisi gas buang kendaraan.

\section{HASIL DAN PEMBAHASAN}

\section{Analisa Hasil Pengujian Performa Mesin}

Hasil pengujian daya dan torsi yang terlihat di gambar 1, menunjukkan adanya peningkatan daya dan torsi dengan pemakaian dua jenis busi yang berbeda menggunakan bahan bakar pertalite murni. Dari hasil tersebut dapat dilihat daya maksimum yang dihasilkan oleh busi platinum sebesar 7,14 HP lebih besar dari pada daya maksimum yang dihasilkan oleh busi standar sebesar 6,84 HP, lalu untuk torsi maksimun yang dihasilkan oleh busi standar maupun busi platinum sama besarnya yaitu 6,20 Nm. Dari hasil penggunaan bahan bakar pertalite murni dengan jenis busi yang berbeda didapat jenis busi platinum lebih optimal dilihat daya yang dihasilkan lebih baik dari pada penggunaan jenis busi standar. Dan dibuktikan melalui metode analisa data statistik dengan uji $\mathrm{t}$ (regresi ganda), dengan nilai $\mathrm{T}$ hitung $>\mathrm{T}$ tabel , $(3,087$ $>2,228$ ), maka H0 ditolak, sehingga busi platinum berpengaruh signifikan terhadap daya yang dihasilkan. Dari hasil tersebut kemudian busi platinum dipilih untuk sample pengujian selanjutnya dengan menggunakan variasi bahan bakar terhadap performa mesin dan emisi gas buang kendaraan. Hasil perbandingan pengujian terhadap daya dan torsi dengan penggunaan bahan bakar pertalite 100\% memakai jenis busi standar dan busi platinum dapat dilihat dalam bentuk grafik seperti di bawah ini : 


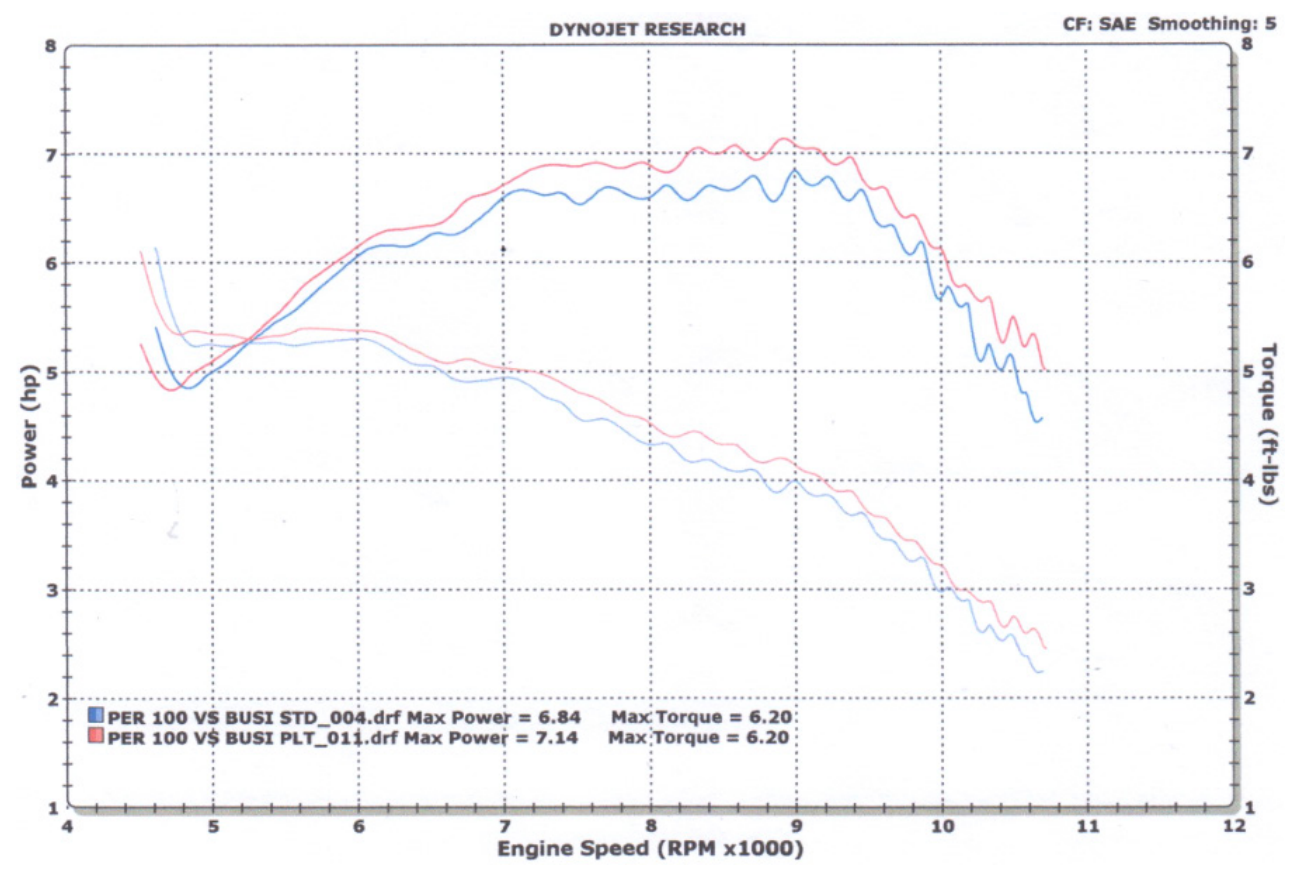

Gambar 1. Perbandingan Hubungan Daya dan Torsi terhadap Putaran Mesin dengan Menggunakan Busi Standar dan Busi Platinum

Kemudian untuk hasil perbandingan pengujian terhadap daya dan torsi dengan menggunakan variasi bahan bakar dengan memakai busi platinum dapat dilihat dalam bentuk grafik seperti di bawah ini:

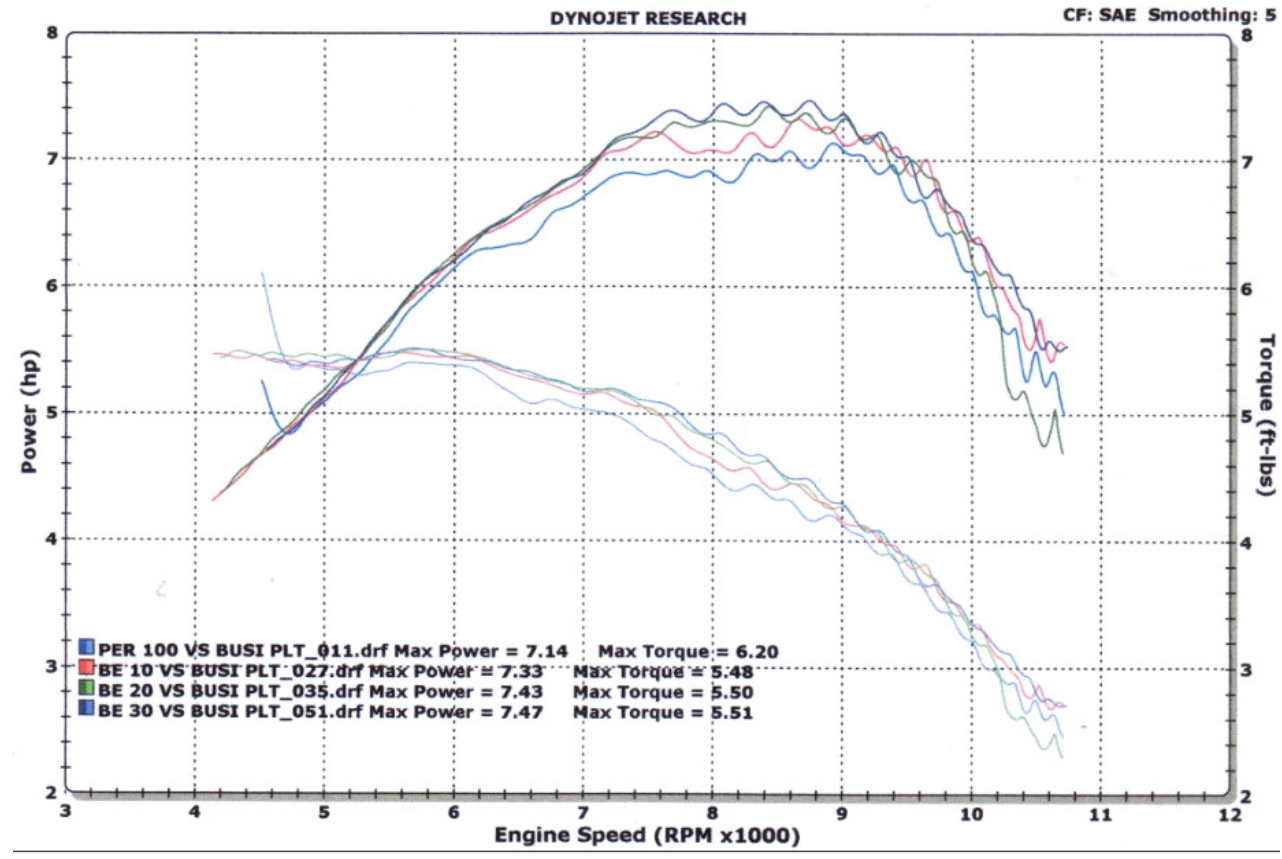

Gambar 2. Perbandingan Hubungan Daya dan Torsi terhadap Putaran Mesin dengan Menggunakan Variasi Bahan Bakar

Berdasarkan data hasil pengujian daya maksimal yang dicapai oleh mesin sebesar 7,47 HP dengan menggunakan bahan bakar BE 30\%, sedangkan pengujian pada torsi maksimal yang dicapai oleh mesin sebesar 6,20 Nm dengan menggunakan bahan bakar pertalite 100\%. Dilihat 
secara grafik dengan variasi bahan bakar yang berbeda daya maksimum semakin meningkat seiring jumlah kadar bioetanol dalam campuran bahan bakar pertalite semakin banyak, namun pada torsi maksimum yang dihasilkan menggunakan bahan bakar BE 30\%, BE 20\% dan BE $10 \%$ lebih rendah dari pada torsi maksimum menggunakan bahan bakar pertalite $100 \%$, secara nilai selisih perbedaannya tidak banyak hanya nol koma baik pada daya maksimum maupun torsi maksimum yang dihasilkan dari variasi bahan bakar yang berbeda, dan dibuktikan melalui metode analisa data statistik dengan Varian ANOVA satu jalan (Uji F), dengan nilai $\mathrm{F}$ hitung $<\mathrm{F}$ tabel , $(0,119<2,82)$, maka H0 diterima, sehingga tidak ada perbedaan yang signifikan daya yang dihasilkan dari variasi bahan bakar, sedangkan untuk torsi dengan nilai $\mathrm{F}$ hitung < F tabel , $(0,340<2,82)$, maka $\mathrm{H} 0$ diterima, sehingga dan $\mathrm{H} 1$ ditolak, tidak ada perbedaan yang signifikan torsi yang dihasilkan dari variasi bahan bakar. Maka dapat ditarik kesimpulan bahwa secara uji analisa data statistik tidak ada perbedaan yang signifikan baik daya maupun torsi yang dihasilkan dari variasi bahan bakar, bisa dikatakan hasil daya dan torsinya sama meskipun dilihat secara grafik sedikit ada perbedaan.

\section{Analisa Hasil Pengujian Konsumsi Bahan Bakar}

Untuk hasil pengujian konsumsi bahan bakar didapat grafik perbandingan jarak tempuh terhadap variasi bahan bakar dengan memakai busi platinum dapat dilihat dalam bentuk grafik seperti di bawah ini :

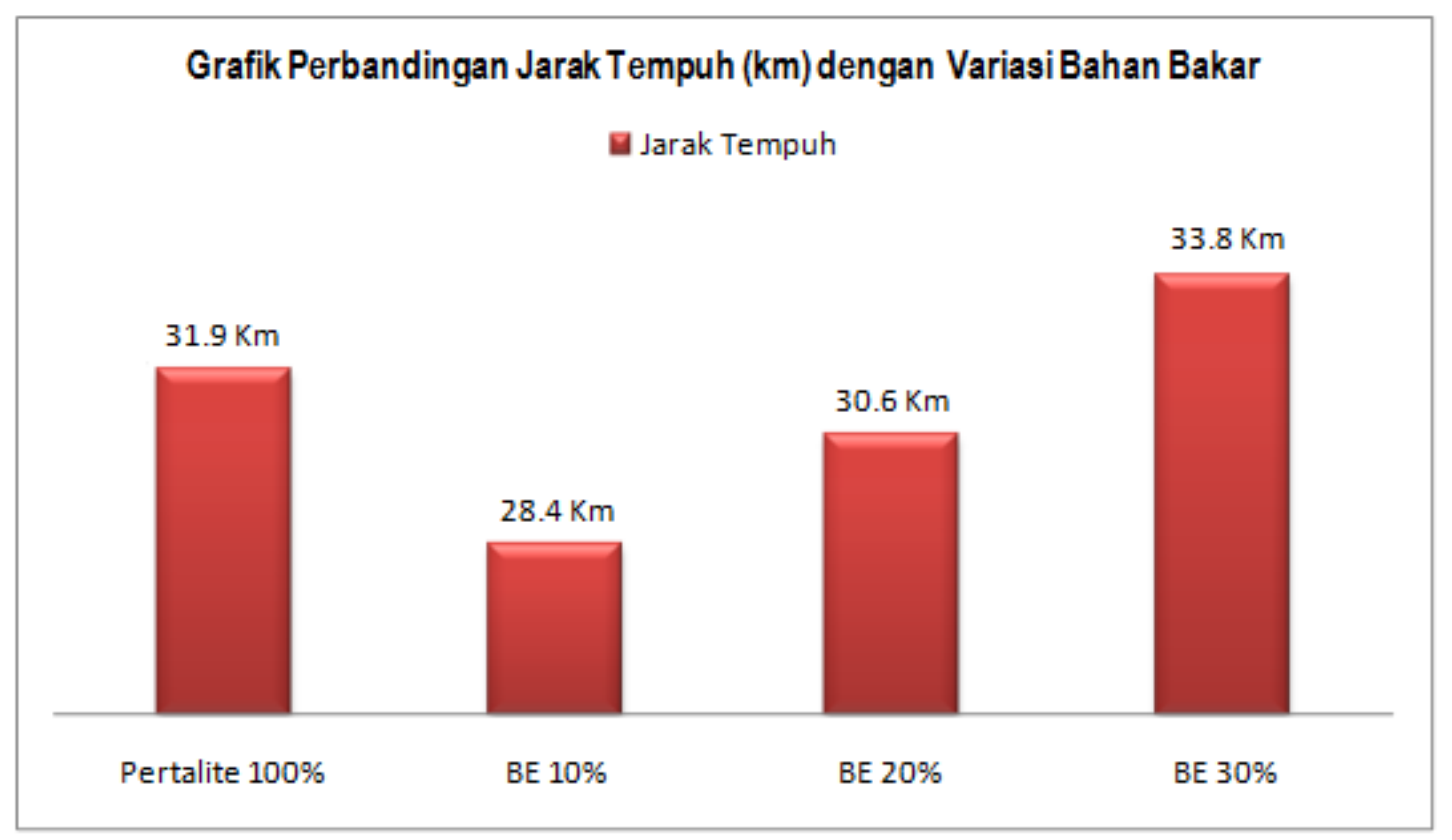

Gambar 3. Perbandingan Jarak Tempuh dengan Variasi Bahan Bakar

Berdasarkan data hasil pengujian konsumsi bahan bakar dengan menggunakan variasi bahan bakar didapat untuk penggunaan variasi bahan bakar dengan menggunakan bahan bakar BE 30\% hasil konsumsi bahan bakarnya lebih hemat dilihat jarak tempuhnya lebih jauh. Dilihat secara grafik dengan variasi bakar yang berbeda jarak tempuh semakin meningkat (lebih jauh) seiring jumlah kadar bioetanol dalam campuran bahan bakar pertalite semakian banyak, namun konsumsi bahan bakar dengan menggunakan bahan bakar $\mathrm{BE} 10 \%$ dan $\mathrm{BE}$ $20 \%$ jarak tempuhnya lebih rendah (dekat) dari pada menggunakan bahan bakar pertalite 100\%. Sedangkan penggunaan bahan bakar BE 30\% jarak tempuhnya lebih jauh yaitu 33,8 Km dari pada penggunaan bahan bakar pertalite $100 \%$ yaitu $31,9 \mathrm{Km}$ dengan selisih jarak tempuh $1,9 \mathrm{Km}$ 
yang menandakan bahwa memakai bahan bakar BE 30\% lebih hemat 5,9\% dari pada memakai bahan bakar pertalite $100 \%$. Namun secara analisa data statistik apakah jarak tempuh yang dicapai menggunakan variasi bahan bakar nilai rata-ratanya sama atau tidak. Dan dibuktikan melalui metode analisa data statistik dengan uji One Sample t, dengan nilai $\mathrm{T}$ hitung $<\mathrm{T}$ tabel , $(-413,211<3,182)$, maka H0 diterima sehingga nilai rata-rata jarak tempuh yang dicapai dengan menggunakan variasi bahan bakar tidak sama. Maka dapat ditarik kesimpulan bahwa secara uji analisa data statistik nilai rata-rata jarak tempuh yang dicapai dengan menggunakan variasi bahan bakar tidak sama. Jadi penggunaan bahan bakar BE 30\% jarak tempuhnya lebih jauh dibandingkan jarak tempuh dengan menggunakan bahan bakar pertalite 100\%, BE 10\% dan BE $20 \%$ yang menandakan bahwa penggunaan bahan bakar BE 30\% lebih hemat.

\section{Analisa Hasil Pengujian Kadar Emisi Gas Buang}

Untuk hasil pengujian kadar emisi gas buang karbon monoksida (CO) didapat grafik perbandingan kadar CO terhadap variasi bahan bakar seperti pada gambar 4, dibawah ini :

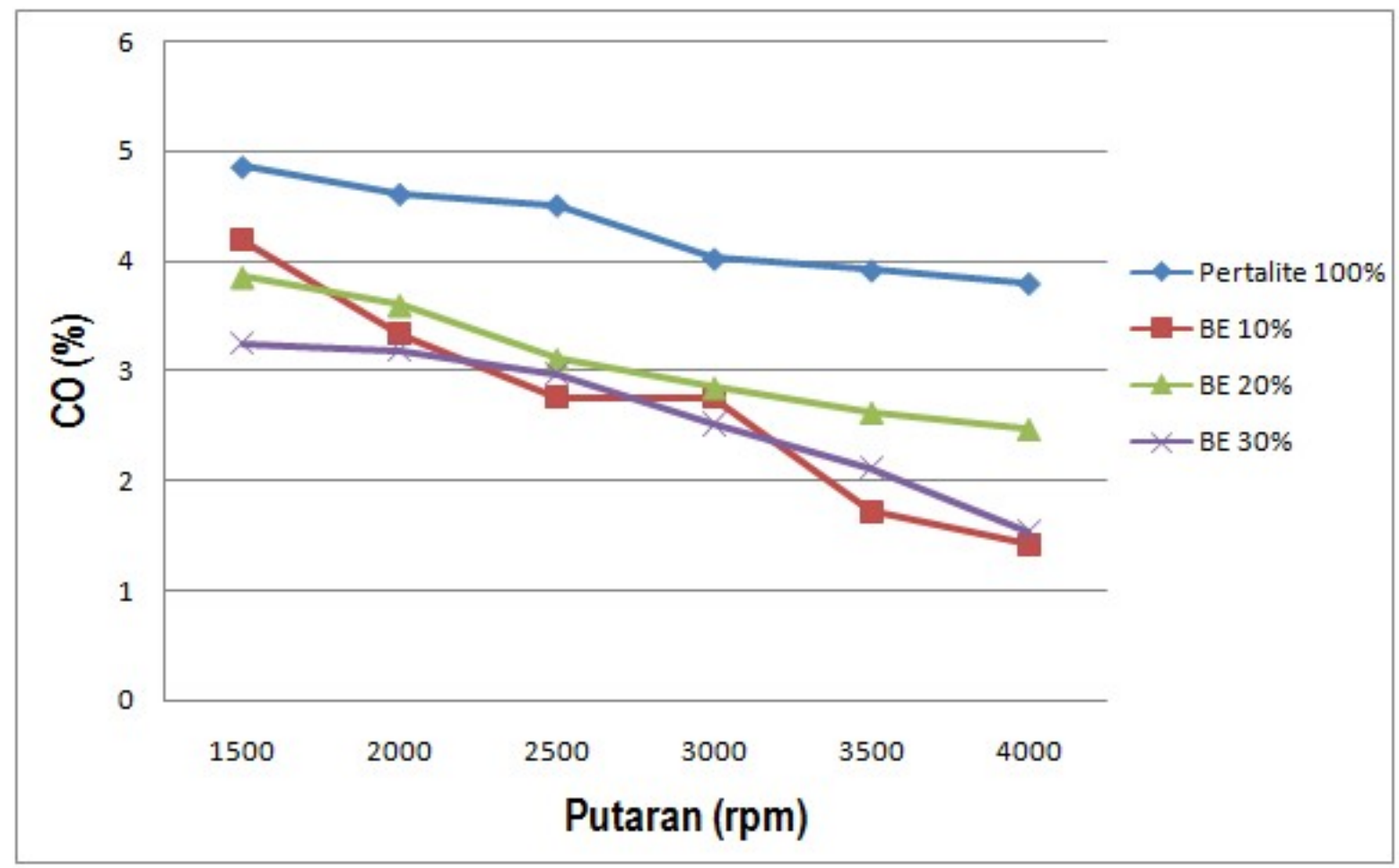

Gambar 4. Perbandingan Hubungan Kadar CO terhadap Putaran Mesin dengan Menggunakan Variasi Bahan Bakar

Berdasarkan data hasil pengujian kadar CO didapat penggunaan bahan bakar BE 30\% hasil kandungan kadar emisi CO lebih rendah dari pada penggunaan bahan bakan pertalite $100 \%$, dan bisa dilihat pada putaran mesin $1500 \mathrm{rpm}$ hasilnya menggunakan Pertalite $100 \%=4,856 \%$ vol, BE $10 \%=4,181 \%$ vol, BE $20 \%=3,850 \%$ vol dan BE $30 \%=3,238 \%$ vol, terjadi penurunan nilai kadar CO cukup signifikan, dan dibuktikan melalui metode analisa data statistik dengan uji varian ANOVA satu jalan (uji F), dengan nilai $\mathrm{F}$ hitung $>\mathrm{F}$ tabel , $(7,285>3,10)$, maka H1 diterima, sehingga ada perbedaan yang signifikan nilai kadar $\mathrm{CO}$ yang dihasilkan dari variasi bahan bakar. Maka dapat ditarik kesimpulan bahwa secara uji analisa data statistik nilai kadar $\mathrm{CO}$ yang dihasilkan dengan menggunakan variasi bahan bakar tidak sama. Jadi penggunaan bahan bakar BE 30\% nilai kadar CO lebih rendah dibandingkan dengan menggunakan bahan 
bakar pertalite $100 \%$, BE $10 \%$ dan BE 20\% yang menandakan bahwa penggunaan bahan bakar BE 30\% dapat menurunkan kadar CO secara signifikan.

Kemudian untuk hasil pengujian kadar emisi gas buang hydrokarbon (HC) didapat grafik perbandingan kadar HC terhadap variasi bahan bakar seperti pada gambar 5, dibawah ini :

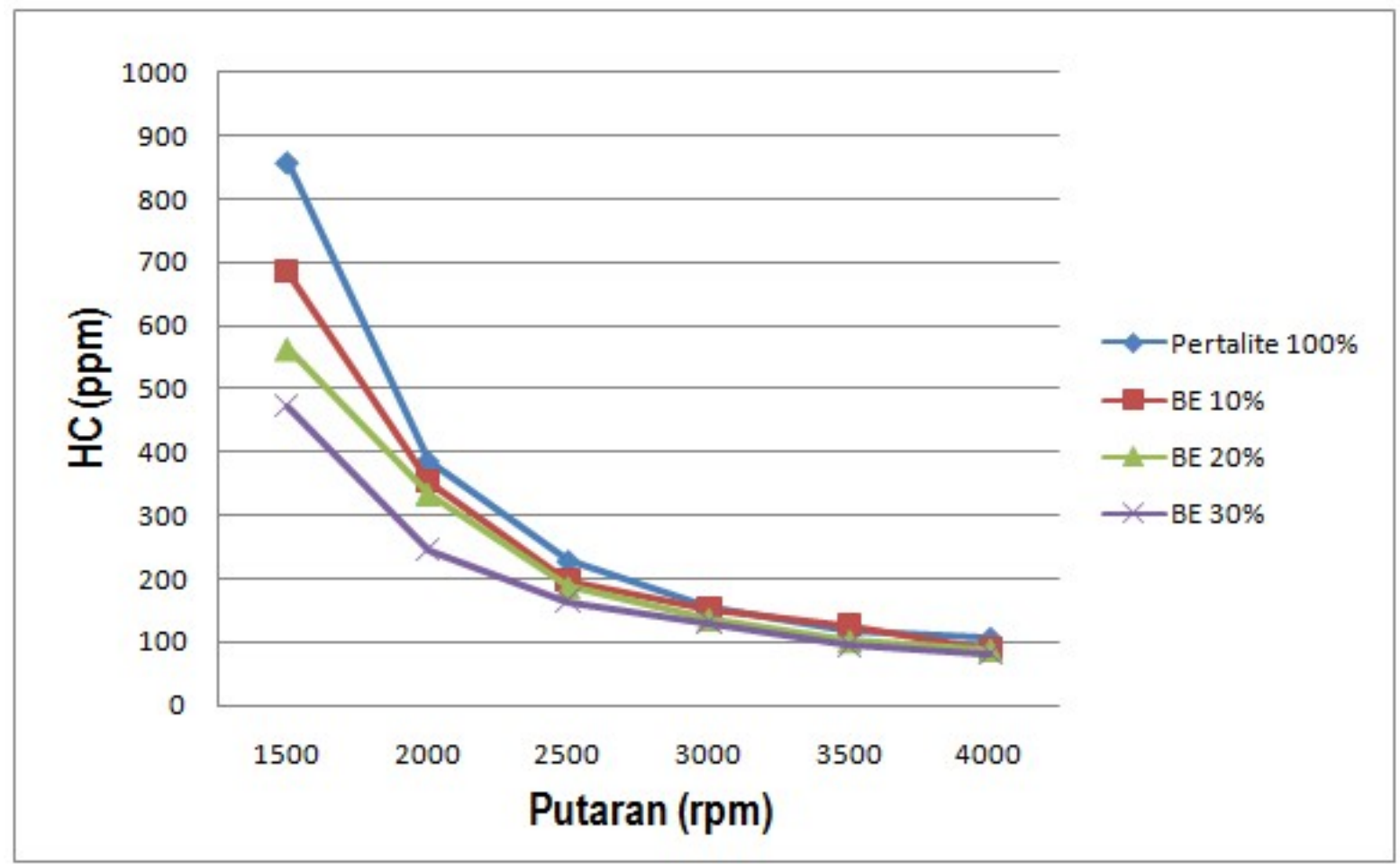
Gambar 5. Perbandingan Hubungan Kadar HC terhadap Putaran Mesin dengan
Menggunakan Variasi Bahan Bakar

Berdasarkan data hasil pengujian kadar $\mathrm{HC}$ didapat penggunaan bahan bakar $\mathrm{BE} 30 \%$ hasil kandungan kadar emisi HC lebih rendah dari pada penggunaan bahan bakar pertalite $100 \%$, dan bisa dilihat pada putaran mesin $1500 \mathrm{rpm}$ hasilnya menggunakan Pertalite $100 \%=$ $858 \mathrm{ppm}, \mathrm{BE} 10 \%=684 \mathrm{ppm}, \mathrm{BE} 20 \%=563 \mathrm{ppm}$ dan BE $30 \%=472 \mathrm{ppm}$, terjadi penurunan nilai kadar HC cukup signifikan, namun seiring meningkatnya putaran mesin rpm terutama pada rpm 2500 keatas hasil grafiknya menunjukkan perubahan yang tidak terlalu signifikan, hampir bisa dikatakan sama meskipun dengan menggunakan variasi bahan bakar yang berbeda, seperti pada putaran mesin $3000 \mathrm{rpm}$ hasilnya menggunakan Pertalite $100 \%=153 \mathrm{ppm}, \mathrm{BE}$ $10 \%=152 \mathrm{ppm}, \mathrm{BE} 20 \%=136 \mathrm{ppm}$ dan BE 30\%=132 ppm, secara nilai selisih perbedaannya tidak terlalu signifikan, dan dibuktikan melalui metode analisa data statistik dengan uji varian ANOVA satu jalan (Uji F), dengan nilai $\mathrm{F}$ hitung $<\mathrm{F}$ tabel , $(0,275<3,10)$, maka $\mathrm{H} 0$ diterima, sehingga tidak ada perbedaan yang signifikan kadar HC yang dihasilkan dari variasi bahan bakar. Maka dapat ditarik kesimpulan bahwa secara uji analisa data statistik nilai kadar HC dengan penggunaan variasi jenis bahan bakar tidak memberikan perubahan hasil grafik yang signifikan, terutama pada putaran mesin diatas $2500 \mathrm{rpm}$.

\section{KESIMPULAN}

Dari penelitian ini dapat ditarik beberapa kesimpulan sebagai berikut :

1. Penggunaan jenis busi platinum lebih optimal hasilnya dibanding jenis busi standar, dilihat dari daya maksimum yang dihasilkan oleh busi platinum sebesar 7,14 HP lebih besar dari 
pada daya maksimum yang dihasilkan oleh busi standar sebesar 6,84 HP, dan dibuktikan melalui metode analisa data statistik dengan uji t didapat nilai $\mathrm{T}$ hitung $>\mathrm{T}$ tabel , $(3,087$ $>2,228$ ), maka H0 ditolak, sehingga busi platinum berpengaruh signifikan terhadap daya yang dihasilkan.

2. Daya maksimum didapat pada penggunaan bahan bakar BE $30 \%$ sebesar $7,47 \mathrm{HP}$, lalu daya terendah didapat pada penggunaan bahan bakar Pertalite 100\% sebesar 7,14 HP, Sedangkan torsi maksimum didapat pada penggunaan bahan bakar pertalite $100 \%$ sebesar $6,20 \mathrm{Nm}$, lalu untuk torsi terendah didapat pada penggunaan bahan bakar BE 10\% sebesar $5,48 \mathrm{Nm}$, dan dibuktikan melalui metode analisa data statistik dengan Varian ANOVA satu jalan (Uji F), untuk daya didapat nilai $\mathrm{F}$ hitung $<\mathrm{F}$ tabel,$(0,119<2,82)$, sedangkan untuk torsi didapat nilai $\mathrm{F}$ hitung $<\mathrm{F}$ tabel , $(0,340<2,82)$, maka $\mathrm{H} 0$ diterima, tidak ada perbedaan yang signifikan daya dan torsi yang dihasilkan dari variasi bahan bakar.

3. Konsumsi bahan bakar menggunakan bahan bakar BE 30\% lebih hemat dari pada penggunaan bahan bakar Pertalite 100\%, BE 10\% dan BE 20\% dilihat jarak tempuhnya lebih jauh, dan dibuktikan melalui metode analisa data statistik dengan uji One Sample $\mathrm{t}$, didapat nilai $\mathrm{T}$ hitung $<\mathrm{T}$ tabel,$(-413,211<3,182)$, maka H0 diterima sehingga nilai rata-rata jarak tempuh yang dicapai dengan menggunakan variasi bahan bakar tidak sama.

4. Penggunaan bahan bakar BE 30\% dapat menurunkan kadar CO yang cukup signifikan pada putaran mesin $1500 \mathrm{rpm}$, dan dibuktikan melalui metode analisa data statistik dengan uji varian ANOVA satu jalan (uji F), didapat nilai $\mathrm{F}$ hitung $>\mathrm{F}$ tabel , $(7,285>3,10)$, maka $\mathrm{H} 1$ diterima, sehingga ada perbedaan yang signifikan nilai kadar $\mathrm{CO}$ yang dihasilkan dari variasi bahan bakar. Sedangkan penggunaan bahan bakar bioetanol dapat menurunkan kadar HC pada putaran rendah, seperti terlihat pada putaran mesin 1500 rpm terjadi penurunan nilai kadar HC cukup signifikan, namun untuk putaran mesin diatas $2500 \mathrm{rpm}$, perubahan penurunan kadarnya tidak terlalu signifikan, hampir bisa dikatakan sama, dan dibuktikan melalui metode analisa data statistik dengan uji varian ANOVA satu jalan (Uji $\mathrm{F})$, dengan nilai $\mathrm{F}$ hitung $<\mathrm{F}$ tabel,$(0,275<3,10)$, maka H0 diterima, sehingga tidak ada perbedaan yang signifikan kadar HC yang dihasilkan dari variasi bahan bakar.

\section{DAFTAR PUSTAKA}

[1] Handayani, S. (2005). Pemanfaatan Bioetanol Sebagai Bahan Bakar Pengganti Bensin. Semarang: Fakultas Teknik Universitas Diponegoro.

[2] Indartono, Y. (2005). Bioetanol Alternatif Energi Terbarukan: Kajian Prestasi Mesin dan Implementasi di Lapangan. http://www.energi.lipi.go.id. Diakses 16 Oktober 2016.

[3] Zhang, Y \& Zhao, H. (2013). CAI combustion of gasoline and its mixture with ethanol in a 2-stroke poppet valve DI gasoline engine. Fuel. Elsevier. Vol 109. Pages 661-668.

[4] Ghazikhani, M \& Hatami, M. (2014). Experimental investigation of exhaust temperature and delivery ratio effect on emissions and performance of a gasoline-ethanol two-stroke engine. Thermal Engineering. Elsevier. Vol 2. Pages 82-90.

[5] Wang, X \& Chen, Z. (2015). The effects of hydrous ethanol gasoline on combustion and emission characteristics of a port injection gasoline engine. Thermal Engineering. Elsevier. Vol 6. Pages 147-154.

[6] Iodice, P \& Senature, A. (2015). Cold start emissions of a motorcycle using ethanolgasoline blended fuels. Energy Procedia. Elsevier. Vol 45. Pages 809-818.

[7] Sudarmanta, B., Junipitoyo, B., \& Putra, A.K.B. (2016). Influence Of The Compression Ratio And Ignition Timing On Sinjai Engine Performance With 50\% Bioethanol-Gasoline 
Blended Fuel. ARPN Journal of Engineering and Applied Sciences. Vol 11. No 4.

[8] Putrasari, Y, Nur, A. \& Muharam, A. (2012). Performace and emission characteristic on a two cylinder DI diesel engine fuelled with ethanol-diesel blends. Energy Procedia. Elsevier. Vol 32. Pages 21-30.

[9] Berg, C. (2004). World Fuel Ethanol Analysis and Outlook. http://www.distill.com/ world-fuel-ethanol-A\&O-2004.html. Diakses 17 Oktober 2016.

[10] Anonim. (2007). Bioetanol. http://www.energi.lipi.go.id/bioetanol.html. Diakses 18 Oktober 2016 